Article

\title{
Multiple Stressors at the Land-Sea Interface: Cyanotoxins at the Land-Sea Interface in the Southern California Bight
}

\author{
Avery O. Tatters ${ }^{1, *}$, Meredith D.A. Howard ${ }^{2}$, Carey Nagoda ${ }^{3}$, Lilian Busse $^{4}$, Alyssa G. Gellene ${ }^{1}$ \\ and David A. Caron ${ }^{1}$ \\ 1 Department of Biological Sciences, University of Southern California, 3616 Trousdale Parkway, Los Angeles, \\ CA 90089-0371, USA; gellene@usc.edu (A.G.G.); dcaron@usc.edu (D.A.C.) \\ 2 Southern California Coastal Water Research Project, 3535 Harbor Boulevard, Suite 110, Costa Mesa, \\ CA 92626, USA; meredithh@sccwrp.org \\ 3 San Diego Regional Water Quality Control Board, 2375 Northside Drive, Suite 100, San Diego, CA 92108, \\ USA; carey.nagoda@waterboards.ca.gov \\ 4 German Federal Environmental Agency, Umweltbundesamt, Wörlitzer Platz 1, 06844 Dessau, Germany; \\ lilian.busse@uba.de \\ * Correspondence: tatters@usc.edu; Tel.: +213-821-2123
}

Academic Editor: Luis M. Botana

Received: 11 February 2017; Accepted: 3 March 2017; Published: 9 March 2017

\begin{abstract}
Blooms of toxic cyanobacteria in freshwater ecosystems have received considerable attention in recent years, but their occurrence and potential importance at the land-sea interface has not been widely recognized. Here we present the results of a survey of discrete samples conducted in more than fifty brackish water sites along the coastline of southern California. Our objectives were to characterize cyanobacterial community composition and determine if specific groups of cyanotoxins (anatoxins, cylindrospermopsins, microcystins, nodularins, and saxitoxins) were present. We report the identification of numerous potentially harmful taxa and the co-occurrence of multiple toxins, previously undocumented, at several locations. Our findings reveal a potential health concern based on the range of organisms present and the widespread prevalence of recognized toxic compounds. Our results raise concerns for recreation, harvesting of finfish and shellfish, and wildlife and desalination operations, highlighting the need for assessments and implementation of monitoring programs. Such programs appear to be particularly necessary in regions susceptible to urban influence.
\end{abstract}

Keywords: cyanobacteria; cyanotoxin; estuary; microcystin; anatoxin; cylindrospermopsin; nodularin; saxitoxin; Southern California Bight

\section{Introduction}

Cyanobacteria are ancient, ubiquitously distributed prokaryotes that have global biogeochemical and environmental significance in freshwater ecosystems. Some of these organisms are sources of bioactive metabolites that include recognized toxic compounds with human health significance [1,2]. Cyanobacteria are able to proliferate or bloom, sometimes to astonishingly high densities, in virtually all water types, although blooms show great variability in species composition, distribution, and magnitude. Bloom events have been reported at increasing frequency and intensity worldwide [3], and have been primarily attributed to trends of eutrophication, and warming of fresh waters associated with the changing climate [4-7]. Their ever-increasing prevalence is impacting and occasionally impairing the use of freshwater recreational water bodies, drinking water sources, and products designated for human consumption [8,9]. 
Cyanobacterial blooms can have a range of deleterious effects on water quality with possible far-reaching consequences. Concentrations of specific cyanotoxins in drinking water supplies, for instance, are now a priority concern of the World Health Organization (WHO) and the United States Environmental Protection Agency (US EPA) [10-12]. Humans may also encounter these chemicals by consuming contaminated finfish and shellfish, and via agricultural products irrigated with toxin-laden water [13-16]. Various cyanotoxins are also consequential to domestic animals, livestock, and wildlife, sometimes resulting in significant mortality events $[15,17]$. The best-studied and arguably most prevalent of these compounds are the cyclic heptapeptide microcystins, followed by nodularins [18-20]. Additional concerns include the small-molecule alkaloid saxitoxins, cylindrospermopsins, and anatoxins $[1,21,22]$.

The associated effects of cyanobacterial blooms are not always immediate or acute, but can have a variety of longer-term/downstream consequences, including the disruption of normal ecosystem function [23]. For example, surface and sub-surface proliferations are able to decrease benthic vegetation by reducing light penetration through the water column. Additionally, the eventual senescence and sinking of decomposing cyanobacterial biomass can decrease dissolved oxygen concentrations, leading to hypoxia and a potential negative feedback cycle that favors the persistence of cyanobacteria [24].

In recent years, there has been increased recognition of various marine harmful algal blooms along the west coast of North America [25,26]. Despite heightened awareness of marine-sourced toxins in coastal ecosystems, and cyanotoxins in freshwater, the notion of cyanotoxin production within and/or transport into these coastal ecosystems has been largely ignored. Toxigenic cyanobacteria and/or cyanotoxins have been documented in a few estuaries in central California [27-29], but the extent and significance of their presence was not determined. Recent events and studies in the Monterey Bay National Marine Sanctuary, CA and the Puget Sound, WA highlight potentially widespread issues [30,31], but documentation of cyanobacterial community composition and associated toxins in brackish water/estuaries along the west coast of North America is still rudimentary, particularly in southern California.

Here we present the results of a discrete sample-based survey conducted in estuarine ecosystems and coastal lagoons along the Southern California Bight during September 2015. The recognition of harmful genera and occasionally toxins in streams [32], lakes/lentic water bodies [30,33], and rivers [33] that lead to the coast prompted this coordinated sampling effort at the land-sea interface. The objectives were to identify potential toxin-producing cyanobacterial taxa and to determine if specified cyanotoxins were present in detectable quantities within these brackish water ecosystems. We report the presence of multiple toxigenic species, and sometimes multiple cyanotoxins, at various locales in the Bight, raising the need for monitoring in these ecosystems.

\section{Results}

\subsection{Santa Barbara/Ventura Counties}

Fifteen cyanobacterial genera were identified at twelve sites in Santa Barbara/Ventura County. Aphanothece, Anabaena, Calothrix, Chroococcus, Cylindrospermum, Cylindrospermopsis, Dolichospermum, Lyngbya, Leptolyngbya, Merismopedia, Nodularia, Nostoc, Oscillatoria, Phormidium and Tolypothrix (Table 1, Figure 1). The number of cyanobacterial genera observed at each sampling site ranged from one to nine in Santa Barbara/Ventura County. Anabaena (species $n \geq 3$ ) was the most commonly observed genus ( 5 of 12 sites) and the Goleta Slough was the most diverse location in terms of species richness. Cyanotoxins were detected at eight of the twelve sampling sites (Table 2). Anatoxins were detected at Arroyo Hondo, Atascadero Creek, Santa Clara River Estuary, Tecolotito Creek, and the Goleta Slough using ultra high performance liquid chromatography with ultraviolet detection (HPLC-UV) with confirmation by ultra high performance liquid chromatography with fluorescence detection (HPLC-FL) (Agilent Technologies, Santa Clara, CA). Cylindrospermopsin was observed in the Santa Clara River and Calleguas Creek using HPLC-UV. Samples from Atascadero Creek, San Pedro Creek, and the 
Goleta Slough tested positive for microcystins by HPLC-UV, and at least one saxitoxin derivative was detected at Calleguas Creek and the Santa Clara River Estuary using ELISA (Table 2).

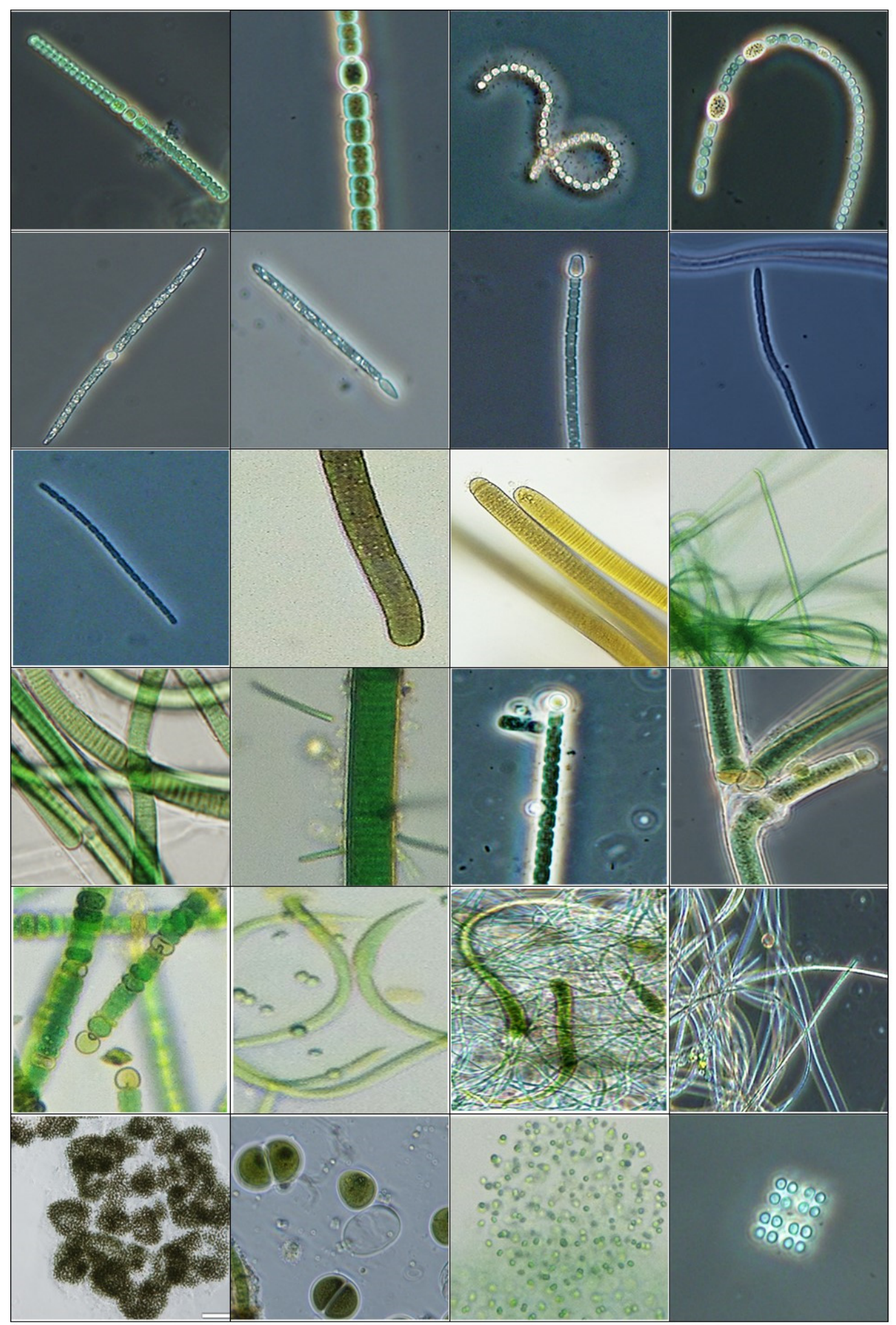

Figure 1. Photomicrograph (10-40x) collage of several cyanobacteria genera encountered in this study. Top row, from left: Anabena sp. 1, Anabaena sp. 2, Dolichospermum sp. 1, Dolichospermum sp. 2; Second row: Aphanizonemon sp., Cylindrospermopsis sp., Cylindrospermum sp., Leptolyngbya sp.; Third row: Pseudanabaena sp., Phormidium sp., Oscillatoria sp., Geitlerinema sp.; Fourth row: Lyngbya sp., Heteroleiblenia sp. on Lyngbya sp., Nostoc sp., Tolypothrix sp. Fifth row: Nodularia sp., Planktolyngbya sp., Calotrhix sp., Leiblenia sp.; Bottom row: Microcystis sp., Chroococcus sp., Aphanocapsa sp., Merismopedia sp. 
The Santa Clara River Estuary is a publically accessible nature preserve. This heavily impacted area receives approximately 8.5 million.gallons $\cdot$ day $^{-1}$ of secondarily treated effluent from the Ventura Water Reclamation Facility. There is also an adjacent, active harbor, the Mandalay Generating Station to the south, intensive agriculture, and numerous golf courses in the region. Salinities at the time of sampling ranged from $3 \%$ to $8 \%$, and chl $a$ concentrations were 24 to $56 \mu \mathrm{g} \cdot \mathrm{L}^{-1}$. There was a nearly equal numerical ratio of diatoms to cyanobacteria in each of the plankton samples. Cyanobacterial genera included Aphanothece, Anabaena, Chroococcus, Geitlerinema, Oscillatoria, and Phormidium (Table 1). The presence of anatoxins and at least one saxitoxin derivative were confirmed (Table 2).

Calleguas Creek is part of a heavily impacted watershed affected from residential areas upstream, industry, and heavy agriculture that forms a drainage system to Mugu Lagoon. Salinities of multiple samples ranged from $1 \%$ to $4 \%$, and chl $a$ was 35 to $43 \mu \mathrm{g} \cdot \mathrm{L}^{-1}$. The potential toxin-producing cyanobacteria were Cylindrospermopsis, Dolichospermum, and Nostoc (present at relatively high abundances). Cylindrospermopsin and at least one saxitoxin derivative were detected in Calleguas Creek (Table 2).

The Goleta Slough is surrounded by an airport, a university, and a heavily populated residential area. This system is also influenced by local agriculture and nutrient concentrations have historically reflected this activity. The potential toxin producing cyanobacteria present were Anabaena, Calothrix, Cylindrospermum, Dolichospermum, Leptolyngbya, Merismopedia, Oscillatoria, and Phormidium (Table 1). Salinities of samples at this location ranged from $1 \%$ to $34 \%$ and chl $a$ ranged from 18 to $\sim 40 \mu \mathrm{g} \cdot \mathrm{L}^{-1}$. The presence of anatoxin-a and microcystins were confirmed in the Goleta Slough (Table 2).

\subsection{Los Angeles County}

Seventeen genera of cyanobacteria were identified from sixteen sites in coastal Los Angeles County. Aphanizonemon, Aphanocapsa, Aphanothece, Anabaena, Calothrix, Chroococcus, Geitlerinema, Gloeocapsa, Heteroleibleinia, Leibleinia, Lyngbya, Leptolyngbya, Merismopedia, Microcystis, Nodularia, Oscillatoria, and Phormidium were present (Table 1, Figure 1), with Chroococcus and Oscillatoria being the most commonly observed ( 5 of 16 sites). The number of cyanobacterial genera observed at each sampling site ranged from zero to nine. Cyanotoxins were detected at five localities in Los Angeles County (Table 2). Anatoxins were detected in Malibu Lagoon and Topanga Creek using HPLC-UV with further confirmation by HPLC-FL. Microcystins, identified with HPLC-UV, were found in Topanga Creek, Topanga Lagoon, and Ballona Creek. At least one saxitoxin derivative was detected in Ballona Lagoon by ELISA (Table 2).

The Ballona Lagoon is bordered by heavy development, including a residential area and active recreational harbor. The cyanobacterial genera Aphanizomenon, Chroococcus, and Leptolyngbya were present in the lagoon. Saxitoxin(s) were detected, but were likely attributed to the relatively high abundance of the marine dinoflagellate Alexandrium catenella in the area (Table 2). Another dinoflagellate, Akashiwo sanguinea, and a mixture of centric diatoms were also present at high relative abundances. Chl $a$ concentration in the sample was $28 \mu \mathrm{g} \cdot \mathrm{L}^{-1}$ and salinity was $30 \%$.

Topanga Lagoon is influenced by light development upstream and is separated from the ocean by a berm during most of the year due to low, and highly seasonal, regional precipitation rates. This watershed is heavily influenced by seasonal rains. Topanga was the most diverse lagoonal site in terms of co-occurring cyanobacterial genera within Los Angeles County in both planktonic and benthic samples. Organisms of interest included Chroococcus, Geitlerinema, Gloeocapsa, Lyngbya, Oscillatoria spp., and Phormidium spp., plus a mixture of diatoms. The salinity ranged from $20 \%$ to $24 \%$ and chl $a$ varied between 13 and $18 \mu \mathrm{g} \cdot \mathrm{L}^{-1}$. Microcystins were detected in benthic samples from Topanga Lagoon (Table 2). 
Table 1. Relative abundances of cyanobacteria genera across fifty-three sampling locations along the Southern California Bight coastline. Dominant $=\mathrm{D}(>50 \%)$, Abundant $=$ A $(25 \%-49 \%)$, Common $=\mathrm{C}(10 \%-24 \%)$, Present $=\mathrm{P}(1 \%-9 \%)$, Rare $=\mathrm{R}(<1 \%)$. Multiple letters per box denotes multiple species of a given genera per site.

\begin{tabular}{|c|c|c|c|c|c|c|c|c|c|c|c|c|c|c|c|c|c|c|c|c|c|c|c|}
\hline Locality & 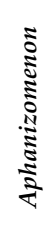 & 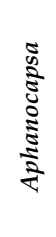 & 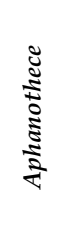 & 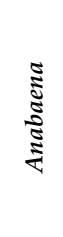 & 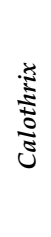 & 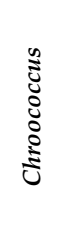 & 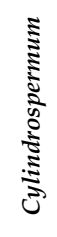 & 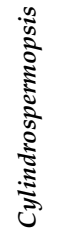 & 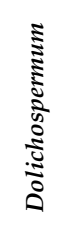 & 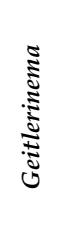 & 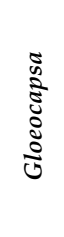 & 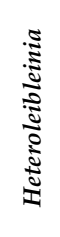 & 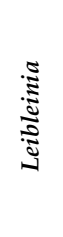 & 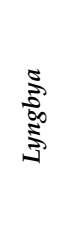 & 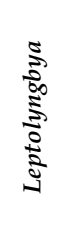 & 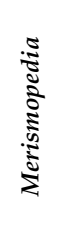 & 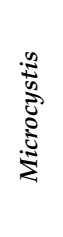 & 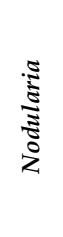 & $\begin{array}{l}\tilde{D} \\
\vec{w} \\
\dot{z}\end{array}$ & 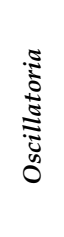 & 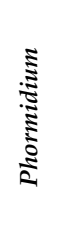 & 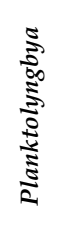 & 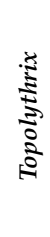 \\
\hline $\begin{array}{l}\text { Arroyo Hondo } \\
\text { Atascadero Creek }\end{array}$ & & & & $\mathrm{AC}$ & $\mathrm{C}$ & & & & & & & & & C & A & & & $\mathrm{P}$ & & $\mathrm{AC}$ & A & & \\
\hline San Jose Creek & & & & AC & $c$ & & $\mathrm{D}$ & & $\mathrm{R}$ & & & & & & & & & $P$ & & & & & \\
\hline San Pedro Creek & & & & & & & & & & & & & & & & $\mathrm{P}$ & & A & & & A & & \\
\hline Tecolotito Creek & & & & & & & & & & & & & & & & & & & $\mathrm{D}$ & & & & \\
\hline Goleta Slough & & & & A & $\mathrm{C}$ & & $\mathrm{R}$ & & $\mathrm{R}$ & & & & & & $\mathrm{P}$ & $\mathrm{P}$ & & & & $\mathrm{C}$ & $\mathrm{R}$ & & $\mathrm{P}$ \\
\hline Devereaux Slough & & & & & & & & & & & & & & $\mathrm{D}$ & & & & & & & & & \\
\hline Ventura Harbor & & & $\mathrm{P}$ & & & & & & & & & & & A & & & & & & A & & & \\
\hline Santa Clara River Estuary & & & $\mathrm{P}$ & $\mathrm{C}$ & & A & & & & $\mathrm{P}$ & & & & & & & & & & A & $\mathrm{R}$ & & \\
\hline Santa Clara River & & & & PP & & & & $\mathrm{P}$ & $\mathrm{P}$ & & & & & & & & & & A & & & & \\
\hline Channel Islands Harbor & & & & & $\mathrm{D}$ & & & & & & & & & & & & & & & & & & \\
\hline Calleguas Creek & & & & & & & & A & A & & & & & & & & & & A & & & & \\
\hline Zuma Lagoon & & & & & $\mathrm{P}$ & & & & & & & & & & $\mathrm{D}$ & A & & & & & & & \\
\hline Malibu Lagoon & & & & PPR & & & & & & & & & & & & & & $\mathrm{P}$ & & A & & & \\
\hline Topanga Creek & & & $\mathrm{P}$ & & & $\mathrm{P}$ & & & & $\mathrm{P}$ & $\mathrm{P}$ & $\mathrm{P}$ & & & $\mathrm{P}$ & $\mathrm{P}$ & & & & CC & $\mathrm{C}$ & & \\
\hline $\begin{array}{l}\text { Topanga Lagoon } \\
\text { Rustic Creek }\end{array}$ & & & & & & A & & & & & $\mathrm{P}$ & $\mathrm{P}$ & & $\mathrm{P}$ & $\mathrm{C}$ & $\mathrm{P}$ & & & & DP & & & \\
\hline Ballona Lagoon & $\mathrm{R}$ & & & & & $\mathrm{D}$ & & & & & & & & & $\mathrm{R}$ & & & & & & & & \\
\hline Marina Del Rey & & & & & & & & & & & & $\mathrm{R}$ & $\mathrm{P}$ & & & & & & & $\mathrm{D}$ & & & \\
\hline Ballona Creek & C & & & $\mathrm{P}$ & & & & & & & & & & & & & $\mathrm{D}$ & & & & & & \\
\hline Del Rey Lagoon & & & $\mathrm{P}$ & & & $\mathrm{D}$ & & & & & & $\mathrm{P}$ & $\mathrm{P}$ & $\mathrm{R}$ & & & & & & & & & \\
\hline Malaga Creek & & $\mathrm{P}$ & & & & & & & & $\mathrm{D}$ & & & & & & A & & & & & & & \\
\hline Colorado Lagoon & & & & & & & & & & & & & & & & & & & & & & & \\
\hline Alamitos Bay & & & & & & & & & & & & & & & & & & & & & & & \\
\hline Mother's Beach & & & & & & $\mathrm{D}$ & & & & & & & & & & & & & & A & & & \\
\hline San Gabriel & & & & & & & & & & & & & & & & & & & & & & & \\
\hline San Gabriel up & & & & & & & & & & & & & & & & & & & & & & & \\
\hline Seal Beach & & & & & & & & & & & & & & & & & & & & & & & \\
\hline Huntington Harbour & & & & & & & & & & & & & $\mathrm{D}$ & & & & & & & & & & \\
\hline Bolsa Chica Channel & & & & & & & & & & & & & $\mathrm{D}$ & & & & & & & & & & \\
\hline Upper Newport & & $\mathrm{D}$ & & & & & & & & & & & $\mathrm{P}$ & & A & & & & & & & & \\
\hline Back Bay & & $\mathrm{D}$ & & & & & & & & & & & & & $\mathrm{C}$ & A & & & & $\mathrm{P}$ & & & \\
\hline Aliso Creek & & & $\mathrm{P}$ & & & $\mathrm{D}$ & & & & & & & $\mathrm{P}$ & & & & & & & & $\mathrm{P}$ & & \\
\hline Salt Creek & & & & & & & & & & & & & & & & & & & & & & & \\
\hline Dana Point Harbor & & & & & $\mathrm{D}$ & & & & & & & & & & & & & & & & & & \\
\hline
\end{tabular}


Table 1. Cont

\begin{tabular}{|c|c|c|c|c|c|c|c|c|c|c|c|c|c|c|c|c|c|c|c|c|c|c|c|}
\hline Locality & 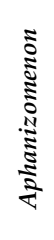 & 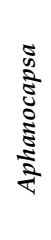 & 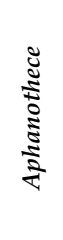 & 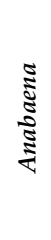 & U. & 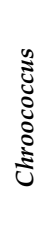 & 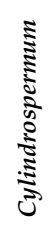 & 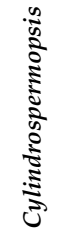 & 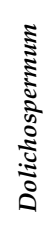 & 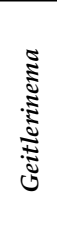 & 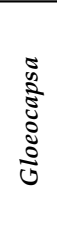 & 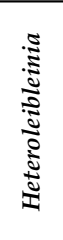 & 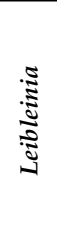 & 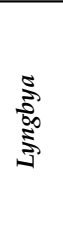 & $\begin{array}{l}5 \\
5 \\
0 \\
5 \\
5 \\
0 \\
0 \\
0 \\
0\end{array}$ & 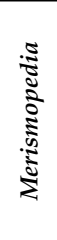 & 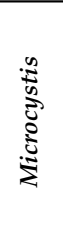 & 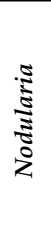 & $\begin{array}{l}\stackrel{\mathscr{D}}{0} \\
\dot{0} \\
\dot{z}\end{array}$ & 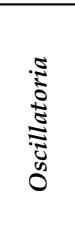 & 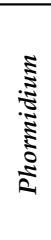 & 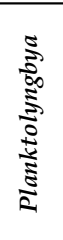 & 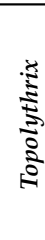 \\
\hline $\begin{array}{c}\text { San Juan Creek } \\
\text { San Mateo Creek }\end{array}$ & & $\mathrm{P}$ & & & & & & & & & & & & & & & & & & DAC & & & \\
\hline $\begin{array}{l}\text { Santa Margarita } \\
\text { Oceanside Harbor }\end{array}$ & & & & $\mathrm{P}$ & & & A & & & & & & $\mathrm{R}$ & & $\mathrm{R}$ & & & A & & $\mathrm{P}$ & & & \\
\hline San Luis Rey River & & & & & & & & A & & & & & & & & & $\mathrm{D}$ & & & & & & \\
\hline Buena Vista Creek/Lagoon & & & & & & & & $\mathrm{D}$ & & & & & & & & & A & & & $\mathrm{CC}$ & & & \\
\hline Agua Hendionda & & & & & & & & & & & & & & $\mathrm{D}$ & & & & & & & & & \\
\hline Batiquitos Lagoon & & & & A & & & & & & & C & & & & C & & & A & $\mathrm{P}$ & $\mathrm{P}$ & & & \\
\hline San Elijo Lagoon & & & & & & A & & & & & & & & & & & & & & $\mathrm{D}$ & & $\mathrm{P}$ & \\
\hline Los Penasquitos Lagoon & & & & & $\mathrm{P}$ & & & & & & & & & $\mathrm{D}$ & & & & & & & & & \\
\hline San Dieguito River & & $\mathrm{D}$ & & & & & & & & & & & & & & & & & & & & & \\
\hline San Diego Creek & & & & A & & $\mathrm{R}$ & & & & & & & $\mathrm{R}$ & & $\mathrm{P}$ & C & & & & $\mathrm{D}$ & & & \\
\hline Loma Alta Creek & $\mathrm{R}$ & & & & & $\mathrm{P}$ & $\mathrm{P}$ & & & & & & & & A & & $\mathrm{P}$ & & & & A & & \\
\hline Mission Bay & & & & & $\mathrm{P}$ & & & & & & & & & C & $\mathrm{D}$ & & & & & & & & $\mathrm{P}$ \\
\hline San Diego Bay & & & & & & & & & & C & & & & & $\mathrm{D}$ & & & & & & & & \\
\hline Tijuana River/Estuary & & & & A & & A & & & $\mathrm{P}$ & & $\mathrm{P}$ & & & & & $\mathrm{P}$ & & & & & & & \\
\hline Sweetwater River & & & & $\mathrm{R}$ & & & & & & & & & & & & $\mathrm{P}$ & & $\mathrm{P}$ & & A & A & & \\
\hline
\end{tabular}


Table 2. Cyanotoxin prevalence across fifty-three sampling locations along the Southern California Bight coastline.

\begin{tabular}{|c|c|c|c|c|c|}
\hline Locality & Anatoxins & Cylindro-Spermopsins & Microcystins & Saxitoxins & Nodularins \\
\hline Arroyo Hondo & + & - & - & - & - \\
\hline Atascadero Creek & + & - & + & - & - \\
\hline San Jose Creek & - & - & - & - & - \\
\hline San Pedro Creek & - & - & - & - & - \\
\hline Tecolito Creek & + & - & - & - & - \\
\hline Goleta Slough & + & - & + & - & - \\
\hline Devereaux Slough & - & - & - & - & - \\
\hline Ventura Harbor & - & - & - & - & - \\
\hline Santa Clara River Est/Lagoon & + & - & - & + & - \\
\hline Santa Clara River & - & + & + & - & - \\
\hline Channel Islands Harbor & - & - & - & - & - \\
\hline Calleguas Creek & - & + & - & + & - \\
\hline Zuma Lagoon & - & - & - & - & - \\
\hline Malibu Lagoon & + & - & - & - & - \\
\hline Topanga Creek & + & - & + & - & _- \\
\hline Topanga Lagoon & - & - & + & - & - \\
\hline Rustic Creek & - & - & - & - & - \\
\hline Ballona Lagoon & - & - & - & + & - \\
\hline Marina Del Rey & - & - & - & - & - \\
\hline Ballona Creek & - & - & + & - & - \\
\hline Del Rey Lagoon & - & - & - & - & - \\
\hline King Harbor & - & - & - & - & - \\
\hline Malaga Creek & - & - & - & - & - \\
\hline Colorado Lagoon & - & - & - & - & - \\
\hline Alamitos Bay & - & - & - & - & - \\
\hline Mother's Beach & - & - & - & - & - \\
\hline San Gabriel River & - & - & - & - & - \\
\hline San Gabriel River upstream & - & - & - & - & - \\
\hline Seal Beach & - & - & - & - & - \\
\hline Huntington Harbour & - & - & - & - & - \\
\hline Bolsa Chica Channel/Basin & - & - & - & - & - \\
\hline Upper Newport & - & - & - & - & - \\
\hline Back Bay & - & - & + & - & - \\
\hline Aliso Creek & - & - & - & - & - \\
\hline Salt Creek & - & - & - & - & - \\
\hline Dana Point Harbor & - & - & - & - & - \\
\hline San Juan Creek & + & - & - & + & - \\
\hline San Mateo Creek & - & - & - & - & - \\
\hline Santa Margarita & + & - & + & + & + \\
\hline Oceanside Harbor & - & - & - & - & - \\
\hline San Luis Rey River & - & - & - & - & - \\
\hline Buena Vista Creek/Lagoon & + & + & + & - & - \\
\hline Agua Hendionda & - & - & - & - & - \\
\hline Batiquitos Lagoon & + & - & + & + & - \\
\hline San Elijo Lagoon & - & - & + & + & - \\
\hline Los Penasquitos & - & - & - & - & - \\
\hline San Dieguito River & - & - & - & - & - \\
\hline San Diego Creek & - & - & - & - & - \\
\hline Loma Alta Creek & - & - & + & + & - \\
\hline Mission Bay & - & - & - & - & - \\
\hline San Diego Bay & - & - & - & - & - \\
\hline Tijuana River/Estuary & - & - & + & - & - \\
\hline Sweetwater River & - & - & + & + & - \\
\hline
\end{tabular}

\subsection{Orange County}

Nine cyanobacterial genera were identified at nine sampling locations within Orange County, including Aphanocapsa, Aphanothece, Calothrix, Chroococcus, Leibleinia, Leptolyngbya, Merismopedia, Oscillatoria, and Phormidium (Table 1; Figure 1). The most commonly observed cyanobacteria were Leibleinia and Leptolyngbya (4 of 9 sites). Cyanotoxins were detected at two of eight sites; Newport Back Bay and San Juan Creek. Microcystins were found in Back Bay using HPLC-UV and saxitoxin(s) in San Juan Creek by ELISA. Anatoxins were also detected at San Juan Creek by screening with HPLC-UV and confirmed using HPLC-FL (Table 2).

Newport Back Bay is a densely populated residential area that receives runoff from the surrounding community as well as influence from boating and other recreational activities. 
This sampling location was the most diverse in terms of co-occurring genera in all of Orange County with Aphanocapsa, Lyngbya, Leptolyngbya, Merismopedia, and Oscillatoria present. A water sample with $15 \mu \mathrm{g} \cdot \mathrm{L}^{-1} \mathrm{chl} a$ and salinity of $6 \%$ contained at least two microcystin derivatives (Table 2).

San Juan Creek enters the Pacific Ocean at Doheny State Beach Lagoon. This watershed is moderately developed and receives runoff from agriculture and other point-sources. Potentially toxic cyanobacteria included Aphanocapsa and three species of Oscillatoria that were not observed at other sampling sites in Orange County. A benthic sample from San Juan Creek tested positive for anatoxins and at least one saxitoxin derivative (Table 2), while toxins were not detected in the plankton sample from that location. The salinity was $8 \%$ and no chl $a$ measurements on benthic samples were obtained. The corresponding sub-surface water sample had a chl $a$ concentration of $12 \mu \mathrm{g} \cdot \mathrm{L}^{-1}$.

\subsection{San Diego County}

Twenty one genera were identified from fifteen sites in San Diego County. These taxa were Aphanocapsa, Aphanothece, Anabaena, Calothrix, Chroococcus, Cylindrospermum, Cylindrospermopsis, Dolichospermum, Geitlerinema, Gloeocapsa, Leibleinia, Lyngbya, Leptolyngbya, Merismopedia, Microcystis, Nodularia, Nostoc, Oscillatoria, Phormidium, Planktolyngbya, and Tolypothrix (Table 1, Figure 1). The number of cyanobacterial genera observed at each sampling site ranged from $0 \%$ to $6 \%$. The most commonly observed genera were Anabaena, Leptolyngbya, and Oscillatoria (5 of 15 sites) and the most diverse sampling sites in terms of co-occurring cyanobacterial genera were Loma Alta Creek, Batiquitos Lagoon, San Diego Creek, and the Tijuana River Estuary. Cyanotoxins were detected at seven of fifteen sites in San Diego County (Table 2). Anatoxins were identified in samples from the Santa Margarita River, Buena Vista, and Batiquitos Lagoons using HPLC-UV and HPLC-FL. HPLC-UV was used to identify cylindrospermopsin in the lower salinity reaches of Buena Vista Lagoon as well as microcystins in samples from the Santa Margarita River, Buena Vista Lagoon, Batiquitos Lagoon, San Elijo Lagoon, Loma Alta Creek, Sweetwater River, and the Tijuana River Estuary. Nodularin was identified by HPLC-UV solely in the Santa Margarita River (Table 2). Saxitoxin(s) were detected in the Santa Margarita River, Batiquitos Lagoon, San Elijo Lagoon, Loma Alta Creek, and the Sweetwater River using ELISA (Table 2).

The Buena Vista creek and lagoon system is surrounded by a densely populated residential zone, has several small-scale inputs, and rarely exchanges water with the adjacent Pacific Ocean. This location was sampled in multiple locations including both sub-surface water and benthic grab samples. Potential toxin-producing cyanobacteria included Cylindrospermopsis, Microcystis, and two Oscillatoria spp. Anatoxins, cylindrospermopsin, and microcystins were detected (Table 2). The salinities of samples collected in the area ranged from $2 \%$ to $30 \%$, and chl $a$ concentrations of water samples varied from 8 to $24 \mu \mathrm{g} \cdot \mathrm{L}^{-1}$.

The watershed connecting to Loma Alta Creek is heavily developed, including industry, agriculture, and numerous golf courses. This area was also sampled in multiple locations, including sub-surface water and the benthos. A range of cyanobacteria were identified; Aphanizomenon, Chroococcus, Cylindrospermum, Leptolyngbya, Microcystis, and Phormidium. Microcystins and the presence of at least one saxitoxin derivative were detected in the same benthic sample (Table 2). The salinity among the water samples varied from $1 \%$ to $23 \%$, and chl $a$ ranged from 20 to $\sim 45 \mu \mathrm{g} \cdot \mathrm{L}^{-1}$

Overall, across the entire Southern California Bight, there were twelve sites where two or more cyanotoxins were detected in the same sample ( $23 \%$ of sites). Anatoxins were identified at 11 sites $(21 \%)$, cylindrospermopsin ( 3 sites, $6 \%$ ), microcystins (14 sites; $26 \%$ ), nodularin ( 1 site; $2 \%$ ), and saxitoxin(s) (7 sites; $13 \%$ ) (Table 2$)$.

\section{Discussion}

The prevalence, geographical distribution, health implications, and ecological impacts of cyanobacteria and their associated toxins within estuarine environments and along marine coastlines are very poorly characterized. Our lack of awareness of the potential importance of these aspects 
for ecosystem health has been underscored by recent mortality events among sea otters in the aforementioned Monterey Bay National Marine Sanctuary, whose cause was eventually attributed to the transfer of freshwater-derived microcystins into marine food webs at the river-sea interface in central California $[30,34,35]$. Subsequent studies in the northwest United States and Japan have identified contamination of marine resources from inland/freshwater sources of microcystins [31,36].

Microcystins are not the only cyanotoxins of concern in coastal waters. Nodularins were documented decades ago in food webs of the Baltic Sea [37,38], Oceania [39], Greece, and Portugal [40]. To our knowledge, nodularin was documented for the first time in California during 2015 ([41], this study). Threats to seafood safety from cyanotoxins other than microcystins in brackish waters have also been reported in various parts of the world [42]. At present, marine environments and related consumables are rarely screened for these compounds unless they occur in an area that is known to be at risk. The seminal studies noted above have begun to draw attention to the possibility of cyanobacterial toxins as unanticipated stressors, and potentially multiple stressors when considered together with toxins of marine origin, for organisms living at or near the intersection of marine and freshwater ecosystems.

Our lack of recognition regarding the importance of algal and cyanobacterial blooms and their toxins at these interface ecosystems has been hindered, in part, by distinct fields of study that tend to focus somewhat exclusively on freshwater or marine ecosystems (limnology and oceanography), reinforced by funding compartmentalization which generally funds work on harmful blooms in either domain, but not both. Investigations at the intersection of these environments therefore have been rare. Moreover, research on phytoplankton toxins in Southern California has largely focused on marine algae because of increased awareness resulting from visible manifestations of these blooms, and their correlation with wildlife mass mortality events for nearly two decades [43,44]. In contrast, the widespread distribution of potentially toxic cyanobacteria in freshwater ecosystems across the region has been recognized only recently [32]. As a consequence, scientific recognition and understanding of the importance of cyanotoxins of freshwater origin in estuaries throughout the Southern California Bight (and an unknown number of other regions globally) has significantly lagged behind our knowledge of marine systems.

Here we present new information on the extensive occurrence of potentially toxic cyanobacterial genera, as well as the confirmation of several groups of cyanotoxins, in brackish/marine influenced waters along the coast of the Southern California Bight. We surveyed all accessible brackish waters along the Bight coastline during late summer/early fall because average annual precipitation is minimal at that time and temperature is maximal (conditions which tend to favor proliferation and accumulations of cyanobacteria). We found that potential producers of cyanotoxins existed at high abundances at all sites, and many taxa exhibited wider distributions than previously documented or anticipated. Multiple genera were present at most sites (range of $0-9$, average of 3 genera at each site). Collectively, we identified twenty-three of approximately forty known toxic genera of cyanobacteria. We also detected each of the cyanotoxins investigated and report at least two groups of compounds at twelve sites ( $23 \%$ of all sites). Our findings are based solely on material from discrete water samples collected on filters, rather than dissolved toxins detected using passive, integrative sampling methods such as Solid Phase Adsorption Toxin Tracking $[45,46]$. Thus, we speculate that our approach yielded a lower limit estimate of the number of sites at which toxins were present. Additionally, we may have overlooked some compounds due to low concentrations present in the samples or due to the sensitivity of the UV detector. Nonetheless, this study provides a baseline for future investigations of temporal and spatial distributions of cyanotoxins along the margin of the Southern California Bight.

The specific source(s) of the toxins observed in this study (i.e., cyanobacterial genera responsible for the toxins) are difficult to assess because of the potential that several of the genera observed are capable of producing toxins, and toxigenic species do not always produce toxins. Additionally, different populations of the same taxon may biosynthesize different compounds due to site-specific environmental drivers and genetic composition [47], and toxic and non-toxic strains can occur within 
a species [48,49]. Therefore, the same species may produce toxin(s) in one environment but not another, and specific classes of toxins may be produced by multiple organisms in a given area [50]. In the current study, for example, microcystins were detected at fourteen sites $(26 \%)$ while Microcystis (a major producer of microcystins) was only identified at four (of which 3 sites, 75\%, tested positive), indicating that other taxa were producing microcystins at some of our study sites. Elucidating the specific producers of the cyanotoxins observed at our study sites, their physiological responses to environmental conditions, will allow better understanding of the factors leading to the occurrence of toxins at the land-sea interface.

In addition to strain/species-related variance in toxin production as noted above, cyanobacterial abundances and toxin concentrations exhibit considerable spatial heterogeneity in natural systems due (at least in part) to substantial small-scale variations in environmental conditions [51]. The difference in strain prevalence is partially dictated by physiological response to abiotic factors [52,53]. Most estuaries/brackish waters inherently have complex gradients of abiotic factors, and thus are candidate habitats for finding multiple co-occurring cyanobacteria and associated toxins, a generalization consistent with our findings. Heterogeneity can be pronounced within these systems in the plankton and the benthos. Spatial heterogeneity of cyanobacteria and associated toxins has been reported from lake systems [51,54] and was also evident in the current study. Several of our sites had pronounced differences in vertical and horizontal community structure and cyanotoxins (unpublished), which were partially attributed to salinity. Examples include the Buena Vista Lagoon, the Goleta Slough, the Santa Clara River Estuary, and Loma Alta Creek. Buena Vista, in particular, was dominated by Cylindrospermopsis at salinities of $2 \%_{0}-3 \%$, Microcystis at salinities of $\sim 6 \%_{0}-10 \%$, and Oscillatoria at salinities up to $30 \%$. Cylindrospermopsin was present in a sample with a salinity of $2 \%$, while at $6 \%$, microcystins and anatoxins were also detected. Microcystins were the only compounds identified in samples above $10 \%$. Heterogeneity undoubtedly plays a role in creating highly localized and possibly ephemeral hotspots with elevated toxin concentrations, and complicates the task of obtaining accurate assessments of toxins in estuarine environments.

We anticipated that sites in our study adjacent to or within urbanized areas might demonstrate greater cyanobacterial diversity or the presence of multiple toxins compared to less developed locations because of increased nutrient loading contributed by developed areas. In general, cyanobacterial proliferations in fresh water and harmful algal blooms in coastal ecosystems appear to be increasing with the alteration of water quality parameters affected by human population expansion, large scale droughts, and other climate induced shifts $[6,55,56]$. Factors such as temperature, nutrients (concentrations, speciation and ratios), and conductivity undoubtedly influence the growth, biomass, toxin production, and types of cyanobacteria present (succession patterns) [52]. However, a clear relationship between toxin occurrence and drainage from highly urbanized sites was not evident in our survey. We observed relatively similar amounts of biomass and diversity across highly urbanized versus less-urbanized areas, although highly influenced sites such as the Santa Clara River Estuary, Marina del Rey, Ballona Lagoon, and the San Gabriel and Tijuana Rivers did have higher relative abundances of diatoms and dinoflagellates compared to (relative to) cyanobacteria. Overall, few positive samples were obtained in southern Los Angeles County and Orange County, arguably the most urbanized areas in our study region. We speculate that the high percentage of impervious surfaces in urbanized areas, highly channelized water movement, and possibly anthropogenic substances that might adversely affect cyanobacterial growth and accumulation may have limited bloom development. These factors may explain the lack of correlation between urbanization and cyanobacterial toxins.

Multiple cyanotoxins in discrete water samples were detected at several locations in the present study (12 sites; $23 \%$ ). Such co-occurrences of cyanotoxins have recently been reported in ponds/lakes [57-60], drinking water reservoirs [61,62], rivers [63], and brackish waters [64]. These mixtures, consisting of chemicals that often exhibit different modes of biochemical action, are sources of contamination with potentially important but currently poorly defined health implications. Combined 
with the potential for toxins of marine origin, these biotoxins may act in an additive or synergistic manner, as multiple physiological stressors for organisms living at the land-sea interface.

We have documented a previously undocumented environmental and public health concern relating to cyanobacterial toxins along the coastline of the Southern California Bight. Our results provide a clearer recognition of the connections between freshwater, estuarine, and marine habitats with respect to our understanding of cyanobacteria and their toxins. Future studies documenting seasonality and interannual variability in toxin presence, spatial heterogeneity within these ecosystems, quantitative data on multiple toxins, and the identity of toxin producers will enable the implementation of surveillance and monitoring efforts for cyanobacteria and cyanotoxins at the land-sea interface in Southern California waters.

\section{Methods}

\subsection{Sample Collection and Sites}

A survey was conducted during the third week of September 2015 to begin assessing cyanotoxins and toxin producers in coastal ecosystems along the Southern California Bight. Samples were collected from sub-surface and benthic locations at each site when possible. At least $500 \mathrm{~mL}$ were collected for water samples, while grabs of visible mats/substrate were collected for benthic samples and placed into whirl-pak ${ }^{\mathrm{TM}}$ bags. More than one sample was obtained at each site when multiple features were visibly present. All samples were placed into coolers and returned to the lab within twenty four hours of collection. A total of 53 sites (Figure 2) are listed with GPS coordinates in Table S1.

\subsection{Cyanobacterial Taxonomy}

Potential toxin-producing cyanobacteria were identified to the genus level according to Komárek [65-71]. Briefly, samples were homogenized by successive inversions and an aliquot was poured into $20 \mathrm{~mL}$ tissue culture dishes, settled overnight, and viewed under an Olympus CKX41 inverted microscope (Olympus America, Center Valley, PA, USA)

Chlorophyll $a$ analysis and salinity (ancillary measurements).

Samples for chlorophyll $a(\mathrm{Chl} a)$ measurements were filtered in duplicate onto $25 \mathrm{~mm}$ GF/F filters (GE Whatman, Marlborough, MA, USA). $5 \mathrm{ml}$ of 90\% acetone was added and each vial was allowed to extract for twenty-four hours at $-20^{\circ} \mathrm{C}$ in the dark. Chl $a$ was determined using a Turner Designs 10-AU fluorometer (Turner Designs, Sunnyvale, CA, USA) [72]. Salinity was measured with a handheld refractometer.

\subsection{Cyanotoxin Screening/Assessment}

Cyanotoxins were not quantified in this survey. The specific goals of this study were to determine what types of cyanotoxins were present and locate sites with multiple toxins in the region. Particulate material was collected on $47 \mathrm{~mm}$ GF/F filters to obtain sufficient cyanobacterial biomass from sub-surface water samples. The filters were subjected to three freeze-thaw cycles in a minimal amount of $10 \%$ aqueous methanol. After the third cycle, the volume was adjusted to $1 \mathrm{~mL}$ with $50 \%$ aqueous methanol and agitated to a slurry with a glass rod. The samples were filtered into multiple $1.5 \mathrm{~mL}$ amber glass HPLC vials using a glass luer-lock syringe and $13 \mathrm{~mm} 0.22 \mu \mathrm{m}$ PFTE filters. Subsamples diluted with nanopure water or $50 \%$ aqueous methanol were used for analysis and the remainder stored at $-20{ }^{\circ} \mathrm{C}$. A duplicate $25 \mathrm{~mm} \mathrm{GF} / \mathrm{F}$ filter was taken for saxitoxin analysis and extracted with $10 \%$ aqueous methanol. 


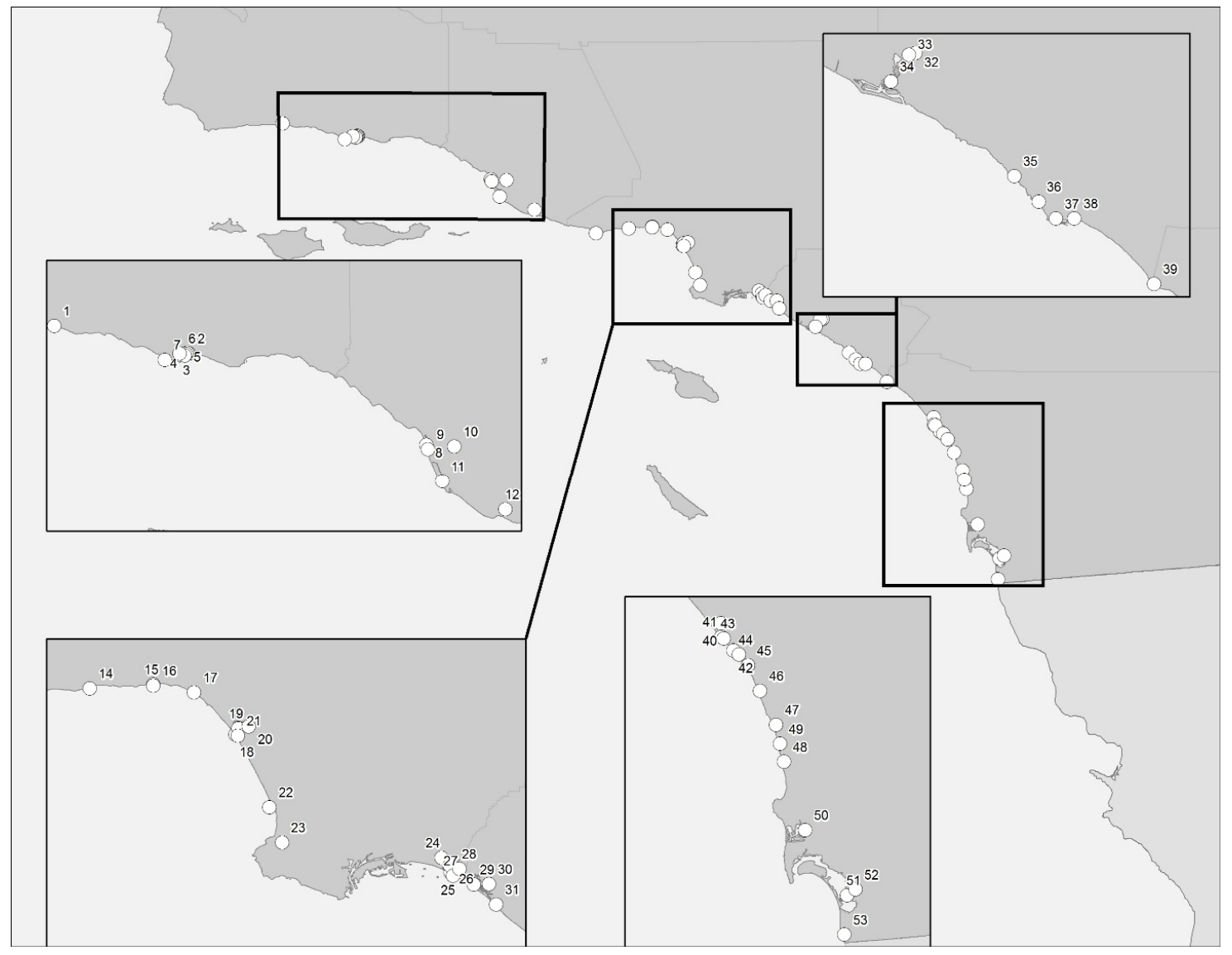

Figure 2. Map depicting fifty-three sampling locations along the Southern California Bight coastline. Santa Barbara and Ventura Counties (\#1-12) 1 = Arroyo Hondo, $2=$ Atascadero Creek, 3 = San Jose Creek, 4 = San Pedro Creek, 5 = Tecolotito Creek, 6 = Goleta Slough, 7 = Devereaux Slough, 8 = Ventura Harbor, 9 = Santa Clara River Estuary, 10 = Santa Clara River, 11 = Channel Islands Harbor, 12 = Calleguas Creek. Los Angeles County (\#13-28), 13 = Zuma Lagoon, 14 = Malibu Lagoon, 15 = Topanga Creek, 16 = Topanga Lagoon, 17 = Rustic Creek, 18 = Ballona Lagoon, $19=$ Marina Del Rey, 20 = Ballona Creek, 21 = Del Rey Lagoon, 22 = King Harbor, 23 = Malaga Creek, 24 = Colorado Lagoon, 25 = Alamitos Bay, 26 = Mother's Beach, 27 = San Gabriel River, 28 = San Gabriel River upstream. Orange County (\#29-39), 29 = Seal Beach, 30 = Huntington Harbour, 31 = Bolsa Chica Channel/Basin, 32 = San Diego Creek, 33 = Upper Newport, $34=$ Back Bay, $35=$ Aliso Creek, 36 = Salt Creek, 37 = Dana Point Harbor, 38 = San Juan Creek, 39 = San Mateo Creek. San Diego County (\#40-53), 40 = Santa Margarita River, 41 = Oceanside Harbor, 42 = Loma Alta Creek, 43 = San Luis Rey River, $44=$ Buena Vista Creek/Lagoon, 45 = Agua Hendionda, $46=$ Batiquitos Lagoon, $47=$ San Elijo Lagoon, $48=$ Los Penasquitos, 49 = San Dieguito River, 50 = Mission Bay, 51 = San Diego Bay, 52 = Sweetwater River, 53 = Tijuana River/Estuary.

Cyanotoxin analysis was primarily conducted using ultra high performance liquid chromatography with HPLC-UV using an Agilent Infinity 1260. Separation was carried out with an Agilent Zorbax RRHD Eclipse Plus C18, $2.1 \times 50 \mathrm{~mm}, 1.8 \mu \mathrm{m}$ column (Agilent Technologies, Santa Clara, CA, USA). The method was adapted and modified from $[57,73,74]$. The mobile phase consisted of $\mathrm{A}: \mathrm{H}_{2} 0,0.01 \%$ TFA, B: MeCN, $0.01 \%$ TFA. The elution gradient began with $20 \% \mathrm{~B}$ from zero to $4 \mathrm{~min}$, with a transition to $70 \%$ B by $4.2 \mathrm{~min}$. This was followed by an increase to $95 \% \mathrm{~B}$ by $4.6 \mathrm{~min}$ and this was held until $5.4 \mathrm{~min}$, with a subsequent decrease to $20 \% \mathrm{~B}$ by $6 \mathrm{~min}$, and held for $1.5 \mathrm{~min}$. The flow rate was $1 \mathrm{~mL} / \mathrm{min}$ and the column was heated to $30^{\circ} \mathrm{C}$. Anatoxin-a and derivatives were considered 'anatoxin positive' due to lack of ion fragmentation patterns obtained from HPLC-UV 
analysis. Any putative anatoxin positives were followed with more specific methodology using the same HPLC that involves derivatization with n-BFD and fluorescence detection [75,76].

Particulate domoic acid was also analyzed in samples that included the diatoms Nitzschia and/or Pseudo-nitzschia by HPLC-UV using a Phenomenex C-18 luna column (Phenomenex, Torrance, CA, USA) with the methodology described in [77]. Screening for saxitoxins was performed using a MAX Signal ELISA kit from Bioo Scientific (Bioo Scientific, Austin, TX, USA). Compounds were identified based on retention times and absorbance spectra facilitated by certified reference standards obtained from the National Resource Council of Canada. Additionally, phenylalanine was purchased from Sigma Aldrich (Sigma Aldrich, St. Louis, MO, USA)

Supplementary Materials: The following are available online at www.mdpi.com/2072-6651/9/3/95/s1, Table S1: List of sampling locations along the Southern California Bight coastline.

Acknowledgments: This study was supported by USC Sea Grant NA14OAR4170089 awarded to David A. Caron and Avery O. Tatters and NCCOS Monitoring and Event Response for Harmful Algal Bloom (MERHAB) grant NA15NOS4780204 awarded to Meredith D.A. Howard, David A. Caron, and Avery O. Tatters. Additional thanks go to members of SCCWRP for sampling in Orange County and some of San Diego County, as well as Jayme Smith for running the saxitoxin ELISA. This is MERHAB publication 203.

Author Contributions: A.O.T., M.D.A.H., C.N., L.B., A.G.G. and D.A.C. conceived and designed the study; A.O.T, A.G.G. and those acknowledged collected samples and performed the study; A.O.T. and D.A.C. analyzed the data; A.O.T. wrote the paper.

Conflicts of Interest: The authors declare no conflict of interest.

\section{References}

1. Carmichael, W.W. Cyanobacteria secondary metabolites-The cyanotoxins. J. Appl. Bact. 1992, 72, 445-459. [CrossRef]

2. Harada, K. Laboratory Analysis of Cyanotoxins. In Toxic Cyanobacteria in Water: A Guide to Their Public Health Consequences, Monitoring, and Management; Chorus, I., Bartram, J., Eds.; E \& FN Spon: London, UK, 1999; pp. 369-405.

3. Brooks, B.W.; Lazorchak, J.M.; Howard, M.D.A.; Johnson, M.V.; Morton, S.L.; Perkins, D.A.; Reavie, E.D.; Scott, G.I.; Smith, S.A.; Steevens, J.A. Are harmful algal blooms becoming the greatest inland water quality threat to public health and aquatic ecosystems? Environ. Toxicol. Chem. 2016, 35, 6-13. [CrossRef] [PubMed]

4. Paerl, H.W.; Huisman, J. Climate change: A catalyst for global expansion of harmful cyanobacterial blooms. Environ. Microbiol. Rep. 2009, 1, 27-37. [CrossRef] [PubMed]

5. Kosten, S.; Huszar, V.L.M.; Bécares, E.; Costa, L.S.; van Donk, E.; Hansson, L.-A.; Jeppesen, E.; Kruk, C.; Lacerot, G.; Mazzeo, N.; et al. Warmer climates boost cyanobacterial dominance in shallow lakes. Glob. Chang. Biol. 2012, 18, 118-126. [CrossRef]

6. Paerl, H.W.; Paul, V.J. Climate change: Links to global expansion of harmful cyanobacteria. Water Res. 2012, 46, 1349-1363. [CrossRef] [PubMed]

7. Loftin, K.A.; Graham, J.L.; Hiborn, E.D.; Lehmann, S.C.; Meyer, M.T.; Dietze, J.E.; Griffith, C.B. Cyanotoxins of inland lakes of the United States-Occurrence and potential recreational health risks in the EPA National Lakes Assessment 2007. Harmful Algae 2016, 56. [CrossRef] [PubMed]

8. Backer, L.; Carmichael, W.; Kirkpatrick, B.; Williams, C.; Irvin, M.; Zhou, Y.; Johnson, T.; Nierenberg, K.; Hill, V.; Kieszak, S.; Cheng, Y.-S. Recreational exposure to low concentrations of microcystins during an algal bloom in a small lake. Mar. Drugs 2008, 6, 389-406. [CrossRef] [PubMed]

9. Ibelings, B.W.; Havens, K.E. Cyanobacterial toxins: A qualitative meta-analysis of concentrations, dosage and effects in freshwater, estuarine and marine biota. Adv. Exp. Med. Biol. 2008, 619, 675-732. [PubMed]

10. WHO. Guidelines for Drinking-Water Quality, 2nd ed.; Health Criteria and Other Supporting Information; World Health Organization: Geneva, Switzerland, 1998; Volume 2.

11. WHO. Recommendations for Public Water Systems to Manage Cyanotoxins in Drinking Water; World Health Organization: Geneva, Switzerland, 2015.

12. U.S. EPA. Cyanobacteria and Cyanotoxins: Information for Drinking Water Systems Fact Sheet; EPA-810F11001; Office of Water: Washington, DC, USA, 2014. 
13. Codd, G.A.; Metcalf, J.S.; Beattie, K.A. Retention of Microcystis aeruginosa and microcystin by salad lettuce (Lactuca sativa) after spray irrigation with water containing cyanobacteria. Toxicon 1999, 37, 1181-1185. [CrossRef]

14. Codd, G.A. Cyanobacterial toxins, the perception of water quality, and the priorisation of eutrophication control. Ecol. Eng. 2000, 16, 51-60. [CrossRef]

15. Carmichael, W.W. Health effects of toxin producing cyanobacteria: "The CyanoHABS". Hum. Ecol. Risk Assess. 2001, 7, 1393-1407. [CrossRef]

16. Drobac, D.; Tokodi, N.; Lujic, J.; Marinovic, Z.; Subakov-Simic, G.; Dulic, T.; Vazic, T.; Nybom, S.; Meriluoto, J.; Codd, G.A.; et al. Cyanobacteria and cyanotoxins in fish ponds and their effects on fish tissue. Harmful Algae 2016, 55, 66-76. [CrossRef] [PubMed]

17. Backer, L.C.; Miller, M. Sentinel animals in a one health approach to harmful cyanobacterial and algal blooms. Vet. Sci. 2016, 3, 8. [CrossRef] [PubMed]

18. Rinehart, K.L.; Harada, K.; Namikoshi, M.; Chen, C.; Harvis, C.A. Nodularin, microcystin-LR and the configuration of Adda. J. Am. Chem. Soc. 1988, 110, 8557-8558. [CrossRef]

19. Tanabe, Y.; Kaya, K.; Watanabe, M.M. Evidence for recombination in the microcystin synthetase (mcy) genes of toxic cyanobacteria Microcystis spp. Mol. Evol. 2004, 58, 633-641. [CrossRef] [PubMed]

20. Dittmann, E.; Fewer, D.P.; Neilan, B.A. Cyanobacterial toxins: Biosynthetic routes and evolutionary roots. FEMS 2013, 37, 23-43. [CrossRef] [PubMed]

21. Metcalf, J.S.; Banack, S.A.; Lindsay, J.; Morrison, L.F.; Cox, P.A.; Codd, G.A. Co-occurrence of $\beta$ - $N$-methylamino-L-alanine, a neurotoxic amino acid with other cyanobacterial toxins in British waterbodies, 1990-2004. Environ. Microbiol. 2008, 10, 702-708. [CrossRef] [PubMed]

22. Gorham, P.R. Toxic algae. In Algae and Man; Jackson, D., Ed.; Plenum Publishing Corp.: New York, NY, USA, 1964; pp. 307-336.

23. Havens, K.E. Cyanobacteria blooms: Effects on aquatic ecosystems. Adv. Exp. Med. Biol. 2008, 619, $733-747$. [PubMed]

24. Zilius, M.; Bartoli, M.; Mariano Bresciani, M.; Katarzyte, M.; Ruginis, T.; Petkuviene, J.; Lubiene, I.; Giardino, C.; Bukaveckas, P.A.; de Wit, R.; et al. Feedback mechanisms between cyanobacterial blooms, transient hypoxia, and benthic phosphorus regeneration in shallow coastal environments. Estuaries Coasts 2014, 37, 680-694. [CrossRef]

25. Horner, R.A.; Garrison, D.L.; Plumley, F.G. Harmful algal blooms and red tide problems on the U.S. west coast. Limnol. Oceanogr. 2004, 42, 1076-1088. [CrossRef]

26. Trainer, V.L.; Bates, S.S.; Lundholm, N.; Thessen, A.E.; Cochlan, W.P.; Adams, N.G.; Trick, C.G. Pseudo-nitzschia physiological ecology, phylogeny, toxicity, monitoring and impacts on ecosystem health. Harmful Algae 2012, 14, 271-300. [CrossRef]

27. Lehman, P.W.; Boyer, G.; Hall, C.; Waller, S.; Gehrts, K. Distribution and toxicity of a new colonial Microcystis aeruginosa bloom in the San Francisco Bay Estuary, California. Hydrobiologia 2005, 541, 87-99. [CrossRef]

28. Drake, J.L.; Carpenter, E.J.; Cousins, M.; Nelson, K.L.; Guido-Zarate, A.; Loftin, K. Effects of light and nutrients on seasonal phytoplankton succession in a temperate eutrophic coastal lagoon. Hydrobiologia 2010, 654, 177-192. [CrossRef]

29. Kurobe, T.; Baxa, D.V.; Mioni, C.E.; Kudela, R.M.; Smythe, T.R.; Waller, S.; Chapman, A.D.; Teh, S.J. Identification of harmful cyanobacteria in the Sacramento-San Joaquin Delta and Clear Lake, California by DNA barcoding. Springerplus 2013, 2, 491. [CrossRef] [PubMed]

30. Miller, M.A.; Kudela, R.M.; Mekebri, A.; Crane, D.; Oates, S.C.; Tinker, M.T.; Staedler, M.; Miller, W.A.; Toy-Choutka, S.; Dominik, C.; et al. Evidence for a novel marine harmful algal bloom: Cyanotoxin (microcystin) transfer from Land to Sea Otters. PLoS ONE 2010, 5, e12576. [CrossRef] [PubMed]

31. Preece, E.P.; Moore, B.C.; Hardy, F.J. Transfer of microcystin from freshwater lakes to Puget Sound, WA and toxin accumulation in marine mussels (Mytilus trossulus). Ecotoxicol. Environ. 2015, 122, 98-105. [CrossRef] [PubMed]

32. Fetscher, A.E.; Howard, M.D.A.; Stancheva, R.; Kudela, R.M.; Stein, E.D.; Sutula, M.A.; Busse, L.B.; Sheath, R.C. Wadeable streams as widespread sources of benthic cyanotoxins in California, USA. Harmful Algae 2015, 49, 105-116. [CrossRef] 
33. Howard, M.D.A.; Nagoda, C.; Kudela, R.; Hayashi, K.; Tatters, A.O.; Caron, D.A.; Busse, L.; Brown, J.; Sutula, M.; Stein, E. Microcystin prevaleance throughout lentic water bodies in Southern California. Toxins. in preparation.

34. Gibble, C.M.; Kudela, R.M. Detection of persistent microcystin toxins at the land-sea interface in Monterey Bay, California. Harmful Algae 2014, 39, 146-153. [CrossRef]

35. Gibble, C.M.; Peacock, M.B.; Kudela, R.M. Evidence of freshwater algal toxins in marine shellfish: Implications for human and aquatic health. Harmful Algae 2016, 59, 59-66. [CrossRef] [PubMed]

36. Takahashi, T.; Umehara, A.; Tsutsumi, H. Diffusion of microcystins (cyanobacteria hepatotoxins) from the reservoir of Isahaya Bay, Japan, into the marine and surrounding ecosystems as a result of large-scale drainage. Mar. Pollut. Bull. 2014, 89, 250-258. [CrossRef] [PubMed]

37. Sivonen, K.; Kononen, K.; Carmichael, W.W.; Dahlem, A.M.; Rinehart, K.L.; Kiviranta, J.; Niemela, S.I. Occurrence of the hepatotoxic cyanobacterium Nodularia spumigena in the Baltic Sea and the structure of the toxin. Appl. Environ. Microbiol. 1989, 55, 1990-1995. [PubMed]

38. Repka, S.; Koivula, M.; Harjunpa, V.; Rouhiainen, L.; Sivonen, K. Effects of phosphate and light on growth of and bioactive peptide production by the cyanobacterium Anabaena strain 90 and its anabaenopeptilide mutant. Appl. Environ. Microbiol. 2004, 70, 4551-4560. [CrossRef] [PubMed]

39. Falconer, I.R.; Choice, A.; Hosja, W. Toxicity of edible mussels (Mytilus edulis) growing naturally in an estuary during a water bloom of the blue-green alga Nodularia spumigena. Environ. Toxicol. Water Qual. 1992, 7, 119-123. [CrossRef]

40. Vareli, K.; Jaeger, W.; Touka, A.; Frillingos, S.; Briasoulis, E.; Sainis, I. Hepatotoxic seafood poisoning (HSP) due to microcystins: A threat from the ocean? Mar. Drugs 2013, 11, 2751-2768. [CrossRef] [PubMed]

41. Kudela, R.M. The Year of Crazy. In Proceedings of the Conference Presentation, 8th Symposium on HABs in the U.S., Long Beach, CA, USA, November 2015.

42. Mulvenna, V.; Dale, K.; Priestly, B.; Mueller, U.; Humpage, A.; Shaw, G.; Allinson, G.; Falconer, I. Health risk assessment for cyanobacterial toxins in seafood. J. Environ. Res. Public Health 2012, 9, 807-820. [CrossRef] [PubMed]

43. Scholin, C.A.; Gulland, F.; Doucette, G.J.; Benson, S.; Busman, M.; Chavez, F.P.; Cordaro, J.; DeLong, R.; De Vogelaere, A.; Harvey, J.; et al. Mortality of sea lions along the central California coast linked to a toxic diatom bloom. Nature 2000, 403, 80-84. [CrossRef] [PubMed]

44. Bargu, S.; Goldstein, T.; Roberts, K.; Li, C.; Gulland, F. Pseudo-nitzschia blooms, domoic acid, and related California sea lion strandings in Monterey Bay, California. Mar. Mamm. Sci. 2012, 28, 237-253. [CrossRef]

45. MacKenzie, L.; Beuzenberg, V.; Holland, P.; McNabb, P.; Selwood, A. Solid phase adsorption toxin tracking (SPATT): A new monitoring tool that simulates the biotoxin contamination of filter feeding bivalves. Toxicon 2004, 44, 901-918. [CrossRef] [PubMed]

46. Lane, J.Q.; Roddam, C.M.; Langlois, G.W.; Kudela, R.M. Application of Solid Phase Adsorption Toxin Tracking (SPATT) for field detection of the hydrophilic phycotoxins domoic acid and saxitoxin in coastal California. Limnol. Oceanogr. Methods 2010, 8, 645-660. [CrossRef]

47. Rapala, J.; Sivonen, K.; Lyra, C.; Niemelae, S.I. Variation of microcystins, cyanobacterial hepatotoxins, in Anabaena spp. as a function of growth stimuli. Appl. Environ. Microbiol. 1997, 63, 2206-2212. [PubMed]

48. Chorus, I.; Bartram, J. Toxic Cyanobacteria in Water; A Guide to Their Public Health Consequences, Monitoring and Management; E \& FN Spon: London, UK, 1999.

49. Davis, T.W.; Berry, D.L.; Boyer, G.L.; Gobler, C.J. The effects of temperature and nutrients on the growth and dynamics of toxic and non-toxic strains of Microcystis during cyanobacteria blooms. Harmful Algae 2009, 8, 715-725. [CrossRef]

50. Paerl, H.W.; Otten, T.G. Duelling 'CyanoHABs': Unravelling the environmental drivers controlling dominance and succession among diazotrophic and non- $\mathrm{N}_{2}$-fixing harmful cyanobacteria. Environ. Microbiol. 2015, 18, 316-324. [CrossRef] [PubMed]

51. Carmichael, W.W.; Gorham, P.R. The mosaic nature of toxicity in cyanobacteria blooms. In The Water Environment: Algal Toxins and Health; Carmichael, W.W., Ed.; Plenum Press: New York, NY, USA, 1981; pp. 161-172.

52. Paerl, H.W. Microscale physiological and ecological studies of aquatic cyanobacteria: Macroscale implications. Microsc. Res. Tech. 1996, 33, 47-72. [CrossRef] 
53. Briand, E.; Escoffier, N.; Straub, C.; Sabart, M.; Quiblier, C.; Humbert, J. Spatiotemporal changes in the genetic diversity of a bloom-forming Microcystis aeruginosa (cyanobacteria) population. ISME J. 2009, 3, 419-429. [CrossRef] [PubMed]

54. Cai, Y.; Kong, F.; Shi, L.; Yu, Y. Spatial heterogeneity of cyanobacterial communities and genetic variation of Microcystis populations within large, shallow eutrophic lakes (Lake Taihu and Lake Chaohu, China). J. Environ. Sci. 2012, 24, 1832-1842. [CrossRef]

55. Anderson, D.M.; Burkholder, J.M.; Cochlan, W.P.; Glibert, P.M.; Gobler, C.J.; Heil, C.A.; Kudela, R.M.; Parsons, M.L.; Rensel, J.E.J.; et al. Harmful algal blooms and eutrophication: Examining linkages from selected coastal regions of the United States. Harmful Algae 2008, 8, 39-53. [CrossRef] [PubMed]

56. Howard, M.D.A.; Sutula, M.; Caron, D.A.; Chao, Y.; Farrara, J.D.; Frenzel, H.; Jones, B.; Robertson, G.; McLaughlin, K.; Sengupta, A. Anthropogenic nutrient sources rival natural sources on small scales in the coastal waters of the Southern California Bight. Limnol. Oceanogr. 2014, 59, 285-297. [CrossRef]

57. Pekar, H.; Westerberg, E.; Bruno, O.; Laane, A.; Persson, K.M.; Sundstrom, L.F.; Thim, A.M. Fast, rugged and sensitive ultra high pressure liquid chromatography tandem mass spectrometry method for analysis of cyanotoxins in raw water and drinking water-First findings of anatoxins, cylindrospermopsins and microcystin variants in Swedish source waters and infiltration ponds. J. Chromatogr. A 2016, 1429, 265-276.

58. Graham, J.L.; Loftin, K.A.; Meyer, M.T.; Ziegler, A.C. Cyanotoxin mixtures and taste-and-odor compounds in cyanobacterial blooms from the Midwestern United States. Environ. Sci. Technol. 2010, 44, 7361-7368. [CrossRef] [PubMed]

59. Glekis, S.; Zaoutsos, N. Cyanotoxin occurrence and potentially toxin producing cyanobacteria in freshwaters of Greece: A multi-disciplinary approach. Toxicon 2014, 78, 1-9.

60. Sabart, M.; Crenn, K.; Perriere, F.; Abila, A.; Leremboure, M.; Colombet, J.; Jousse, C.; Latour, D. Co-occurrence of microcystin and anatoxin-a in the freshwater lake Aydat (France): Analytical and molecular approaches during a three-year survey. Harmful Algae 2015, 48, 12-20. [CrossRef]

61. Jancula, D.; Strakova, L.; Sadilek, J.; Marsalek, B.; Babica, P. Survey of cyanobacterial toxins in Czech water reservoirs - the first observation of neurotoxic saxitoxins. Environ. Sci. Pollut. Res. 2014, 21, 8006-8015. [CrossRef] [PubMed]

62. Bittencourt-Oliveira, M.C.; Hereman, T.C.; Cordeiro-Araújo, M.K.; Macedo-Silva, I.; Dias, C.T.; Sasaki, F.F.; Moura, A.N. Phytotoxicity associated to microcystins: A review. Braz. J. Biol. 2014, 74, 753-760. [CrossRef] [PubMed]

63. Borges, H.L.F.; Branco, L.H.Z.; Martins, M.D.; Lima, C.S.; Barbosa, P.T.; Lira, G.A.S.T.; Bittencourt-Oliveria, M.C.; Molica, R.J.R. Cyanotoxin production and phylogeny of benthic cyanobacterial strains isolated from the northeast of Brazil. Harmful Algae 2015, 43, 46-57. [CrossRef]

64. Rodriguez, I.; Rodriguez, C.; Alfonso, A.; Otero, P.; Meyer, T.; Breitenbach, U.; Botana, L.M. Toxin profile in samples collected in fresh and brackish water in Germany. Toxicon 2014, 91, 35-44. [CrossRef] [PubMed]

65. Komárek, J.; Komárková, J. Review of the European Microcystis-morphospecies (Cyanoprokaryotes) from nature. Czech Phycol. 2002, 2, 1-24.

66. Komárek, J.; Komárková, J. Phenotype diversity of the cyanoprokaryotic genus Cylindrospermopsis (Nostocales); review 2002. Czech Phycol. 2003, 3, 1-30.

67. Komárek, J.; Komárková, J. Taxonomic review of the cyanoprokaryotic genera Planktothrix and Planktothricoides. Czech Phycol. 2004, 4, 1-18.

68. Komárek, J.; Zapomĕlová, E. Planktic morphospecies of the cyanobacterial genus Anabaena = subg. Dolichospermum-1. Part: Coiled types. Fottea 2007, 7, 1-31.

69. Komárek, J.; Jerzerová, J.; Komárek, O.; Zapomĕlová, E. Variability of Chroococcus (Cyanobacteria) morphospecies with regard to phylogenetic relationships. Hydrobiologia 2010, 639, 69-83. [CrossRef]

70. Komárek, J. Diversita a Moderní Klasifikace Sinic (Cyanoprocaryota) [Diversity and Modern Classification of Cyanobacteria (Cyanoprokaryota). Dissertation, 1992.

71. Rajaniemi, P.; Hrouzek, P.; Kaštovská, K.; Willame, R.; Rantala, A.; Hoffmann, L.; Komárek, J.; Sivonen, K. Phylogenetic and morphological evaluation of the genera Anabaena, Aphanizomenon, Trichormus and Nostoc (Nostocales, Cyanobacteria). Int. J. Syst. Evol. Microbiol. 2005, 55, 11-26. [CrossRef] [PubMed]

72. Welschmeyer, N.A. Fluorometric analysis of chlorophyll $a$ in the presence of chlorophyll $b$ and pheopigments. Limnol. Oceanogr. 1994, 39, 1985-1992. [CrossRef] 
73. Harada, K.I.; Ohtani, I.; Iwamoto, K.; Suzuki, M.; Watanabe, M.F.; Watanabe, M.; Terao, K. Isolation of cylindrospermopsin from a cyanobacterium Umezakia natans and its screening method. Toxicon 1994, 32, 73-84. [CrossRef]

74. Spoof, L.; Neffling, M.R.; Meriluoto, J. Fast separation of microcystins and nodularins on narrow-bore reversed-phase columns coupled to a conventional HPLC system. Toxicon 2010, 55, 954-964. [CrossRef] [PubMed]

75. James, K.J.; Sherlock, I.R.; Stack, M.A. Anatoxin-a in Irish freshwater and cyanobacteria, determined using a new fluorimetric liquid chromatographic method. Toxicon 1997, 35, 963-971. [CrossRef]

76. James, K.J.; Furey, A.; Sherlock, I.R.; Stack, M.A.; Twohig, M.; Caudwell, F.B.; Skulberg, O.M. Sensitive determination of anatoxin-a, homoanatoxin-a and their degradation products by liquid chromatography with fluorimetric detection. J. Chromatogr.A 1998, 798, 147-157. [CrossRef]

77. Tatters, A.O.; Fu, F.-X.; Hutchins, D.A. High CO2 and silicate limitation synergistically increase the toxicity of Pseudo-nitzschia fraudulenta. PLoS ONE 2012, 7, e32116. [CrossRef] [PubMed]

(c) 2017 by the authors. Licensee MDPI, Basel, Switzerland. This article is an open access article distributed under the terms and conditions of the Creative Commons Attribution (CC BY) license (http:/ / creativecommons.org/licenses/by/4.0/). 